\title{
VIOLENCE BEYOND THE UTOPIAN SOCIETY IN LOIS LOWRY'S THE GIVER
}

\author{
Rendry Hanifa Ak Mallyta \\ University of Jember \\ email: hatpujiati.sastra@unej.ac.id \\ Hat Pujiati \\ University of Jember \\ email: hatpujiati.sastra@unej.ac.id
}

\begin{abstract}
This article discusses violence in a constructed utopian society in The Giver, Lois Lowry's distopian novel. We assume that 'sameness' as the governing system in the novel is the source of violence. Therefore, this article aims to reveal the real conditions beyond the utopian society. Applying genetic structuralism by Lucien Goldmann, we analyze the presentation of society in the novel through the narrative structure and relate them to discourses of American society in 1990s with Author as the bridge of the fiction and real life. The result of this analysis shows that comfort facilities provided by the government in a society is potential to hegemonize people and dehumanize them for the sake of power.
\end{abstract}

Keywords : utopian society, genetic structuralism, worldview

\begin{abstract}
ABSTRAK
Artikel ini mendiskusikan tentang kekerasan dalam masyarakat utopis yang dikontruksi dalam novel distopian berjudul The Giver karya Lois Lowry. Penelitian mengganggap 'sameness' sebagai sistem pemerintahan di masyarakat yang ada dalam novel sebagai sumber dari kekerasan tersebut. Selanjutnya, artikel ini bertujuan untuk menggungkapkan kondisi sebenarrnya dibalik masyarakat utopis ini. Dengan menggaplikasikan teori strukturalisme genetik milik Lucien Golmann, tulisan ini menganalisa tampilan dari masyarakat di novel ini melalui struktur naratif dan menghubungkannya dengan wacana tentang masyarakat Amerika pada tahun 1990an dengan kehidupan penulis sebagai penghubung antara fiksi dan dunia nyata. Hasil dari analisa ini menunjukkan bahwa fasilitas kenyamanan yang disediakan oleh pemerintah dalam masyarakat tersebut merupakan cara untuk mendominasi dan menghilangkan rasa kemanusiaan mereka hanya untuk kepentingan kekuasaan.
\end{abstract}

Kata Kunci: masyakat utopis, strukturalisme genetik, pandangan dunia 


\section{INTRODUCTION}

The Giver is one of Lois Lowry's novels published in 1993. This novel is the first novel of The Giver's Quartet's series; Gathering Blue, (2000), Messenger (2004) and Son (2012). The Giver shows fragility of Utopian society. Lowry creates a flawless society that lack of conflict and suffering with less individual freedom and choice. All members of society tend to abide by the rules. The society seems to be secure and undergoes little problem. Lowry uses Jonas' disclosures to show the weakness of the Utopian society in The Giver. The idealistic society transforms into the non idealistic one when there are many things hidden in the process of making this "perfect" society. The members are filled with no humanity on their mind since they are created to be a robot. The use of genetic structuralism's theory by Lucien Goldmann in the study is to conduct the whole study. Goldmann believes that literary works are a structure. A literary work composed of the structure from the novel (intrinsic elements) or socio history when the novel is written (extrinsic elements). The intrinsic elements are the literary work itself, such as theme, character, characterization, etc. On the other hand, extrinsic elements are about the social background, the author's environment, and the historical background when the author wrote it. Based on the definition above, genetic structuralism will be the tool to examine the problems; first is about Utopian society presented in the novel, second is how American society in 1993, and last is the constructed worldview in the novel.

Lois Lowry's The Giver reflects the unsuccessfulness of social conditions in the Utopian Society. From the incompatibility of the situation happened in the novel, there are several problems are explored :

1.How is the society presented in the novel?

2. How is the social condition of America in 1990s?

3. What is the constructed worldview in the novel?

There are several purposes on writing this thesis. First, to explain the society presented in the novel. Second, is about American society in 1990s. Third, is to find out the worldview constructed in the novel. 
The last is hoped to give contribution both for the institution and the students. It is aimed to help the readers enrich their knowledge and it is also useful to conduct their research especially about Lois Lowry's Novel The Giver,since this novel has never been made as an object of research by Faculty of Humanities students in Jember University.

\section{RESEARCH METHODOLOGY}

The type of this research is qualitative research method. Qualitative research analyzes data based on interpretation of observation. Gray states that "Qualitative research method can take many forms and results from the use of data gathering instruments such as observations, interviews, questionnaires and document analysis. The qualitative research is used to collect data and information which is related to the topic. The researchers usually concerns with theory building, interpreting the data to build concepts and categories that can be brought together into theoretical frameworks (2004: 320). This thesis is composed in some ways. First, the data are collected from the novel and second, library research is needed to gather the information and the data from several books as additional information. The classification of collected data will be divided into four major elements in genetic structuralism. They are human facts, transindividual subject, significant structure and world view (vision $d u$ monde). The research is conducted by genetic structuralism theory. The purpose of this research is to analyze the genetic structuralism's elements on Lois Lowry's The Giver. The construction of perfect society leads the deeply investigation of Lois Lowry's life, when and where she writes the novel. This activity can help the researcher collect some data about situations, cultures and events that influenced her which happened in 1990s. It also refers to historical background about the social condition in America. The investigations about Lowry's life and social condition of America in 1990s as the historical background are the extrinsic elements of the novel. Furthermore, the collected intrinsic and extrinsic elements will lead to the 
next step which is processing the data by using Genetic Structuralism in order to find the worldview constructed in the novel. To apply the theory, dialectic method is used to connect the intrinsic and extrinsic elements. This activity means dialectic method connects the discourse about the construction of perfect society with the author's life and the social condition of America in 1990s.

\section{RESULT}

From the data analysis, it shown that the 'sameness' applied in the society brings failure. The idea of 'Sameness' represents the lack of differences not only their physical but also their beliefs. The purpose is to balance the society by living as a homogeneous group. The society learns that by doing away with differences in citizens such as race and economic differences, their life will be more harmonious. In its implementation, the attempt on making perfect society by eliminating the citizens right only make them numb for the truth. This condition also makes Jonas escape from the society.

\section{DISCUSSION}

In this article, the analysis starts with the society of the novel. The explanation about society in the novel is started by analyzing the condition of the society and the citizens, how the society affects the citizens and how they act toward the rules. The society follows 'sameness' as their guidance for life. The aspects of "sameness" cover everything in the society. First is their individual side.As humans live by paying attention not only on their personal needs but also the social needs, people will need each others. This condition leads people to learn to work together in order achieving their goals, although it is undeniable that some people are rather to stick by their own and ignore others. This selfishness is often becoming problems and put people in chaotic states. Some people tend to choose to put aside their happiness and others interests to get a safe spot in society and this condition is reflecting individualism. Weaver states, earned status, individualism, self-reliance and independence were all necessary values for those who wanted to survive and prosper in the American 
frontier society of the 1800s and 1900s. These values allowed them to succeed and were vital for the country to grow economically (1999, h.10). Americans believe that individual matters are needed in order to achieve their American Dreams. The competitions are tight and people need to fight for their life. This condition shows the willingness to sacrifice everything with purpose finding their ways to success.

As being individual person, people tend to put their personal needs than society needs. It can lead to major destruction on their tolerance. People will become sentiment and heartless. They do not need others to complete their lives because they only believe on their own. Their senses of sympathy become weak and they will become ignorant person.

The individual side removal is depicted by eliminating citizens' senses on their personal needs in order to create unity. Their lives are already organized in exact ways with rules bonding their actions. Eliminating choices and limiting selfconcerned become the way to make citizens obey. On the other hand, social perspective becomes the number one concern in the society. They are assured by putting the individual acts aside, it will decrease the disunity. Citizens will grow as honest people with lack of individual rights. It will be their major concern to live together side by side. This society believes that being individual is a shame, both in thought and appearance. The quotation below shows the condition of individual side removal in the novel.

"But what about the
treatment? The Speaker says
that treatment must take
place." Jonas felt miserable.
Just when the Ceremony was
about to happen, his
Ceremony of Twelve, would
he have to go away
someplace for treatment?
Just because of a stupid
dream?
But his mother laughed again
in a reassuring, affectionate
way. "No, no," she said. "It's just
the pills. You're ready for the
pills, that's all. That's the
treatment for Strirings."
(Lowry, 1993, h.37-38)

The quotation shows that Jonas is obedient. He has already learned about desire and the treatment. He is afraid that this feeling will make him being taken away from his society. Jonas worries that this condition will make him unable to attend the 
upcoming Ceremony of Twelve and he does not want to be different than the others because he is uncomfortable with the idea. It shows that Jonas cares about what happens in his society and he tries to show his effort by attending the event.

By eliminating choices and limiting self-concerned are hoped that it can be the way to control the society. On the other hand, social perspective becomes the number one concern in the society. They are assured by putting the individual acts aside, it will decrease the disunity. Individuality is rejected and social matter is more appreciated.

Second is, their freedom and choice. The novel depicts the limitation of freedom and choice. In order to prevent citizens making the wrong turn by picking the improper choice, the rules are applied. All freedom to choose is very limited, there will be no envies, gaps, and inequality, so that no one will be more superior compare to others. The lack of freedom to choose is a common thing happens in this society.
The novel depicts the limitation of freedom and choice. In order to prevent citizens making the wrong decision by picking the improper choice, the rules are applied. It is very crucial to limit the consequences on making the wrong choice. Since citizens in the society are not allowed to making choice, the choice is decided. Committee equalizes the choice, every choice are made by them. It creates a condition that family units in the society have no blood relations because they are selected randomly with specific and orderly sequences. All freedom to choose is very limited, so there will be no envies, gaps, and inequality, so that no one will be more superior compare to others. The lack of freedom to choose is a common thing happens in this society. It shows from the quotation which related to the concept of freedom and choice.

"But now that I can see colors, at least sometimes, I was just thinking: what if we could hold up things that were bright red, or bright yellow, and he could choose? Instead of the Sameness."

"He might make wrong choices."

"Oh." Jonas was silent for a minute. "Oh, I see what you 
mean. It wouldn't matter for a newchild's toy. But later it does matter, doesn't it? We don't dare to let people make choices of their own."

"Not safe?" The Giver suggested.

"Definitely not safe," Jonas said with certainty. "What if they were allowed to choose their own mate? And chose wrong?

"Or what if," he went on, almost laughing at the absurdity, "they chose their own jobs?"

"Frightening, isn't it?" The Giver said.

Jonas chuckled. "Very frightening. I can't even imagine it. We really have to protect people from wrong choices."

"It's safer." "Yes," Jonas agreed. "Much safer." (Lowry, 1993, h.98-99)

After his ability to see colors, Jonas wonders how if he able to make choices based on those colors, what will happen to their life if they able to choose. Then he comes to realization that choice might bring trouble if they choose wrong. Jonas still believes that deciding about their life is not necessary to do. Jonas assumes if choices are made by themselves, it will only cause more problems. He believes by letting the choice decided and citizens have no need to intervene about it.
The limitations of choices lead to the deprivation of liberty. Citizens are constructed to believe that choices are better to be chosen by. This condition shows that in order to attain equality on choosing, the Leader and the Committee are pressing citizens ability on deciding their own ways by reducing their freedom. The Leader and the Committee believe that 'sameness' is the way to control citizens.

'Sameness' reflects the efforts of the Leader and the Committee to create a place under their rules and one of them are eliminating citizens' freedom. With no freedom and choice, citizens cannot understand the feeling of making the wrong choices because their paths are already chosen. Citizens are also losing their urges to feel the sensation of diversity they can experience from their own choice. 'Sameness' making citizens believe that their lives are designed that ways. Their urges to rebel and disobey the rules are removed. It is also forcing them to shut their life from everything that may destroy their society. Once this system 
becomes the controller of everything, it will be hard to be changed.

Third is, their feeling and emotion. People as part of human being are easily to know what feeling they feel. This novel shows the citizens as emotionless person, being sentimentally on making decision or behaving irrationally are prohibited.

According to Leonhard, if we do not become more proactive on these issues, I worry that an exponential, unfettered, and uncontrolled intelligence explosion in robotics, AI, bioengineering, and genetics will eventually lead to a systematic disregard of the basic principles of human existence, because technology does not have ethics-but a society without ethics is doomed (2016, h.15). Technology as part of human life is important. It is undeniable that mostly people nowadays are addicted to technology. The usage of technology on almost every aspect is advantageous. However, technology cannot do human thinking; its process is different with human brains. The power of technology may affect on human norms and values. It affects human unconsciously.
In the bright side, the useful technology is indeed bringing many benefits that making life more easily, but the effects of people's addicted to technology are having negative effects, such as: the loss of humanity. The loss of humanity may affect people life. By losing their humanity people are created as heartless person. They will lose their tolerances and consciousness toward others. Their capability to express deep feelings and emotions are reducing. They are also having difficulty on knowing the senses they feel. The quotation below shows about the limitation of feeling and emotions.

"Do you love me?"

There was an awkward silence for a moment. The Father gave a little chuckle. Jonas. You, of all people. Precision of language, please!"

"What do you mean?" Jonas asked. Amusement was not at all what he had anticipated. (Lowry, 1993. h.127)

It describes that feeling love is abnormal. Citizens cannot express love, it is considered as a strange word. Jonas also does not realize if saying love is making his father thinks that he picks the wrong word 
to say. Jonas learns that, he will consider appropriate if he says happy or proud instead saying love because love is part of strong feeling. There is no proper emotional attached between the members of the family and the most matter that seems in the family is only his accomplishments.

The limitation of citizens to express their feelings and emotions is part of 'sameness' purposes. Without less senses of emotions, citizens are able to think clearly. They will be more focus on their jobs and they will not let their feelings getting attached. To prevent the undesirable events that tend to make people not united; the "sameness" is also functioning to control feeling and emotion. All citizens in the society are clueless about emotions. It creates them as emotionless person in order to avoid people being sentimental on making decision or behaving irrational.

'Sameness' is being citizens' boundary that impedes them on doing deviated things from the rules. With their emotionless side, the Leader and the Committee's work are easier because citizens already know their responsibilities. 'Sameness' is constructing them as robots that will follow every order from their master. They are also not able to refuse since they are clueless about the real matter.Last is, the perception. The purpose of the society in The Giver is to create a perfect world without war, conflict, hunger, pain, war and other heartbreaking things. 'Sameness' here brings out new perception that different from ordinary perception. The citizens perceptions are sometimes become more cruel or inhuman because their lives are emotionless.

Jonas frowned. "The whole world?" he asked. "I don't understand. Do you mean not just us? Not just the society? Do you mean Elsewhere, too?-" He tried, in his mind, to grasp the concept. "I'm sorry, sir. I don't understand exactly. Maybe I'm not smart enough. I don't know what you mean when you say 'the whole world' or 'generations before him' I thought there was only us. I thought there was only now." (Lowry, 1993. h.77-78)

By learning memories, Jonas also learns about choice but he still believe that it will better if the Committee chooses for the citizens. Their belief that choice is made carefully and it is better that way; making the citizens also assure if they choose they can choose wrong and it 
will cost many consequences. In fact, choosing the wrong one happens to many people, but it gives them lesson to be more tough and careful on choosing. Making wrong choice and also know how to rise back from destruction will give lesson to gain wisdom on life.

The novel depicts about a world where differences are not existed. The gap will not cause problem because citizens in this society have their own way of life. They are afraid that the gap will only bring out disunity within the society; that is why no citizen who is more superior to others.

The society is trying to eliminate sources of unhappiness such as: war, hunger, poverty, hatred, deprivation and many more. The society also believes that by equalizing the amount of love for every person the happiness they get will equal. There is no benefit to be more stands out than others. Otherwise, 'sameness' that citizens thought are ideal, actually hiding many facts. In order to fulfill their purpose, there are many horrible things covered by their rules. All human aspects and all human rights are eliminated. There are no individual right to fight for the one they like, no freedom to choice their own ways and, no feeling to avoid them choosing something emotionally.

Citizens become blind of the truth, they also become cold-hearted. Citizens are shaped into heatless person in order to avoid sentimental feeling dominate their minds. Those facts show that the attempt to create a perfect Utopian world is failed. The safe place is turning into a place citizens become numb of truth. The construction of Utopian world is turning into Dystopian one when citizens' rights are being eliminated to achieve 'sameness'.

The condition of America in 1990s is also influencing the novel. The unstable conditions of America in 1993 makes people living in two different situations; some people are living in finest condition and some are not. This gap is arising some critics because it leads to some bad results such as crime and violence.

The Great Recession in early 1990s, the continuing of social liberalizations, the embrace of environmentalism and 
entrepreneurship are affecting the American's social condition. Many developments especially in western fashion and culture were invented in this age. This kind of fashion was continually becoming a culture spreading by the youth. The society was being accustomed by this kind of action and slowly becoming a culture. A society developed a culture, culture was part of a society and it formed as the result of a society itself, but a culture also could affect a society. This condition affects some authors to bring American society as the background of their stories. They are inspired by the social condition of America and portray it in their literary works.. One of the inspired authors is Lois Lowry in TheGiver. The Giver itself is not portraying the exact life of America in 1990s, since the setting is futuristic world. The condition of America in 1993 is mostly seen as "new era", with the appearance of new cultures that easily absorbed by youth. As youth that commonly rebels or breaking the rules, these new cultures are growing rapidly. Back in 1993's governmental condition, the Presidency has been suffering from Great Recession and wars. These conditions brought the presidential on unstable position such as: having trouble on control and govern citizens. To overcome this chaos, the authorities were sent to handle the problems. There is a relationship between the society and the social condition of America in 1990s. Those discussion lead to the worldview constructed in the novel. According to Goldmann, there is homology between literary structures and society structures. Both of them are products from historical activity (1981, h.29). The connection between literary structures and society structures are bounded by the attitude of a certain class or mental structure and world view itself uses as the adjustments to the social structures. Since, the relation between literary structures and society structures cannot be understood as a direct relation; worldview is needed in order to find the ideology constructed by the author.

The novel explores the wide ranges of development about many aspects happen in the real life. The society in the novel portrays its alienation, its concerns is to keep 
outsiders to prevent the new influence that might be able to destroy them. No tolerance is given to the outsiders. It also demands the social perfection in order to maintain their unity. The society allows citizens to apply suicide, which is depicting the effort to control population.

The idea of 'sameness' represents the lack of differences not only their physical but also their beliefs. The purpose is to balance the society by living as a homogeneous group. The society learns that by doing away with differences in citizens such as race and economic differences, their life will be more harmonious. Lowry as a part of collective subject that has shaped her mindset to have the same world view is implicitly against humans degrading that include treatment of outsiders, intolerance, societal perfection, and physician-assisted suicide. This situation will not solve the society's problem about eliminating conflicts to create perfect place to stay. It only bring suffer because citizens are restricted to do their wishes and to choose on learning from their mistakes. She reminds her readers that a good society is where people are able to express their minds, to explore their limits, and to choose their own ways with reckoning the consequences not only toward themselves but also their environment.

\section{CONCLUSION AND SUGGESTION}

The analysis shows that the society is not as perfect as it seen. Jonas as the main character becomes the person who discovers the truths. The society is portrayed as perfect place to live because the citizens are honest and united. It removes individual rights, freedom to choose, and deep feeling or emotion. The society is also having different perception on their ways of life; called 'sameness'. 'Sameness' becomes the set of rules that control the citizens in order attain peace and harmony. The elimination of war, hunger, poverty, hatred, deprivation and many unhappiness sources are applied in order to prevent the citizens suffer. Equalizing the amount of love for every citizen is necessary because each citizen will accept equal happiness. 
In its accordance to the historical background and based on Goldmann's theory, it will influence her to write a literary work that portray her world view in the real life. Furthermore, analyzing Lowry's life help the researcher get the information about the socio-history which happened in 1990s. It proves that The Giver has the correlation with its context, when and where the novel written. The result of the research shows that the condition of America in 1990s that seen as "new era", affect the appearance of new cultures that easily absorbed by youth. This situation will create mass conflict that lead to chaotic states. The Giver depicts the information about the Leader and the Committee as authorizes who control citizens' life with their own governing system.

The wide range of development about many aspects in the real life is explored in the novel. The novel shows the society is secluded, it means that limiting outsiders in order to avoid new influence that could lead the society into disaster. The social perfection is strongly needed in the society with the purpose to keep their unity. It is shown by the allowance to apply to get "release" as the effort to control the population. It shows the controlling situation against the nature of human being that divers.

Lowry wants to show the failure on the perfect society's setting. Her concerning about a process of degrading against the human nature, such as treatment of outsiders, intolerance, societal perfection, and physician-assisted suicide is shown in her novel. She wants to tell that setting up situation into perfection would not make the society become better place to stay. It is because citizens are pressed against their wills and their consciousness to obey 'sameness'.

Lowry tries to channel her criticism toward the social life. She emphasizes that the creation of good society is not by controlling people but it needs the cooperation and togetherness. By letting people choosing their ways, they learn how to handle the consequences. In the other words, 'sameness' is a failure.

\section{ACKNOWLEDGEMENTS}

My sincere gratitude is hereby extended to the following people who never ceased in helping until this 
article is structured: L. Dyah Purwita Wardani S W W, S.S., M.A. Dr. Eko Suwargono, M. Hum. and Irana Astutinigsih, SS., MA. as my examiners; All of lecturers of English Department who have taught us much precious knowledge during studying at Faculty of Humanities; and All of staffs of Central Library and Faculty of Humanities library for the books and references.

\section{REFERENCES}

Buck, M.B. (1978). The effects of individualism on the American personality. -- Lambda Alpha Journal of Man, v.9, no.1/2, p.25-47Goldmann, Lucien. 1981. Method in the Sociology of Literature. Translated and edited by William Q. Boelhower. England: Basil Blackwell Publisher.

Burgess, A. (2017). Novel: Literature. Encyclopædia Britannica Online, $S$.

v.

"novel"http://www.britannica.c om/art/novel; accessed on April 23, 2017.

Kumar, K. (2010). New Literary History, Volume 41, Number 3, Summer 2010, pp. 549-569

Jameson, F. (2005). Archaeologies of the Future: The Desire Called Utopia and Other Science Fictions. New York: Verso. Hayek, Friedrich August Von. 1960. The Constitution of Liberty. London: University of Chicago Press.

Kurniawan, A. (2014). The Collection of Ideology and Worldview in
Slipknot's Selected Lyrics: An Analysis of the Genetic Structuralism. Jember: English Department, Faculty of Letters, Jember University.

Laurenson, D. and Swingewood. A. (1972). The Sociology of Literature. London: MacGibbon \& Kee Ltd.

Leonhard, G. (2016). Technology vs. Humanity. United States of America by Fast Future Publishing Ltd.

Lowry, L. (1993). The Giver. Boston: Houghton Mifflin Company (http://catherinelucy.org/Docu ments/TeacherFiles/GiverFULLT EXT1 1120201484312 AM.p df)

Lowry, L. (1998). Looking Back: A Book of Memories. Boston: Houghton Mifflin Harcourt

Lowry, L. (2012). Lois Lowry. http://www.loislowry.com/; accessed on June 1, 2016.

Milojević, I. (2002). Definitions and Histories of Utopia, pp. $40-85$.

Oxford Advanced Learner's Dictionary: International Student's Edition - The Eight Edition. 2010. New York: Oxford University Press.

Pettinelli, M. (2014). The Psychology of Emotions, Feelings and Thoughts. _Version 1.130 http://cnx.org/content/m1435 8/1.130/

Ruzbeh, B. et al. (2015). Critical Review on the Idea of Dystopia, Vol. 7, No. 11; 2015 ISSN 19187173 E-ISSN 1918-7181 doi:10.5539/res.v7n11p64.

Published by Canadian Center of Science and Education.

Sargisson, L. (2007). Religious Fundamentalism and Utopianism 
in the 21st Century, Vol 12 (3) copyright.

Pryor, M. (1016). “A Lesson by Megan Pryor"

http://study.com/academy/less on/utopia-dystopia-definitioncharacteristics-

examples.html\#lesson; accessed on May 26, 2016.

Sprow, V. (2013). The Giver. LitCharts, LLCWeb. http://LitCharts.com/LoisLowr
y/TheGiver; accessed on February 27, 2017.

Steven, C. (1990). Elements of the Novel. Portland, Maine: J Weston Walch, Publisher.

Weaver, R.G. (1999). American Cultural Values. Kokusai Bunka Kenshu (Intercultural Training).

Wellek, R. and Warren, A. (1949). Theory of Literature. New York: Harcourt, Brace and Company, Inc. 